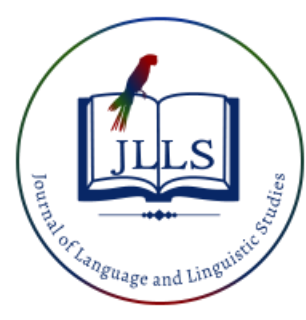

Available online at www.jlls.org

JOURNAL OF LANGUAGE AND LINGUISTIC STUDIES

ISSN: $1305-578 \mathrm{X}$

Journal of Language and Linguistic Studies, 16(4), 1784-1802; 2020

\title{
An examination of reading strategies awareness among Algerian ESP students at the National Higher School for hydraulics
}

\author{
Bensaad Safia $^{\text {al }}$ iD, Ouahmiche Ghania ${ }^{\text {b }}$ iD \\ ${ }^{a}$ University of Oran2 Mohamed ben Ahmed, Oran, Algeria \\ ${ }^{b}$ University of Oran2 Mohamed ben Ahmed, Oran, Algeria
}

\section{APA Citation:}

Bensaad, S., \& Ouahmiche, G. (2020). An examination of reading strategies awareness among Algerian ESP students at the National Higher School for hydraulics. Journal of Language and Linguistic Studies, 16(4), 1784-1802.

Submission Date: $10 / 07 / 2020$

Acceptance Date:24/09/2020

\begin{abstract}
Promoting students' knowledge of the reading process as well as their metacognitive awareness of reading strategies has become a crucial issue of ESP teaching and undoubtedly an obligatory subject in higher education. Relevant to this, the present paper tries to examine Algerian ESP students' awareness and use of reading strategies, especially while reading academic material in English. The study is realized through the administration of Mokhtari and Sheorey's (2002) Survey of Reading Strategies (SORS) to 100 students enrolled in first year engineering classes at the National Higher School for Hydraulics (ENSH), mainly to find out: (1) frequency of students' reported use of different reading strategies (Global, Problem-solving and Support reading strategies); (2) difference(s), if any, between female and male students' reading strategies use; and (3) students reported use of any other strategies which are not included in the SORS. Findings reveal that Algerian ESP students, as medium users of reading strategies in general, tend to use Problem-solving more than other categories of reading strategies; the absence of significant differences between males and females reported use of reading strategies; meanwhile, students report use of some strategies other than those mentioned in Mokhtari and Sheorey's Survey. Consequently, an adapted version of the SORS is designed to fit the Algerian context of EFL for specific purposes.
\end{abstract}

C) 2020 JLLS and the Authors - Published by JLLS.

Keywords: reading strategies; Algerian ESP students; SORS; metacognitive awareness; gender; reading

\section{Introduction}

Reading as a complex cognitive ability has often been perceived as a crucial constituent of language learning, and one of the most significant and complicated language skills. Moreover, reading is certainly the most essential skill to master, especially for students who are studying EFL for specific purposes and must-read specialized subject matter in English. As maintained by Johns and Dudley-Evans (1991), "in ESP practice the simple skill is usually reading because of its primary importance in many EFL ... environments" (p. 305). Additionally, with reference to the importance of acquiring the reading ability

\footnotetext{
${ }^{1}$ Corresponding author.

E-mail address: s.bensaad@ensh.dz
} 
by ESP students, Rezaei et al. (2012) confirm that "more often ESP students' success in their specific subject of study is bound to their ability to read sufficiently in English" (p. 983).

Moreover, reading comprehension as a multifaceted process involves readers to possess a set of intertwined strategies to be able to extract and construct meaning from the reading material. Therefore, the efficient utilization of reading strategies is urged more often than not as the most effective means by which EFL learners can enhance their understanding of texts. For that, EFL learners' mastery of these strategies has become inevitable especially for those studying EFL for specific purposes. In fact, reading strategies are usually conceptualized as the actions (conscious and/or subconscious) that skilled readers proceed through before, while, and after reading to interact with and interrogate texts (Pressley \& Afflerbach, 1995, as cited in Kymes, 2007, p.11). In the same vein, it is believed that good readers apply more strategies more frequently and more effectively than poor readers (Olshavsky, 1977; Paris et al., 1983, as cited in Pani, 2004, p. 355).

Furthermore, EFL learners' awareness of reading strategies has been given particular interest by many researchers in the last decades. Accordingly, a plethora of studies have been conducted to investigate the use of reading strategies by EFL readers from different perspectives, predominantly in terms of measuring the frequency of use of these strategies when dealing with academic documents in English. For this, Mokhtari and Sheorey's (2002) Survey of Reading Strategies has been adopted by a wide range of researchers as an effective research instrument to measure EFL/ESL students' awareness of metacognitive reading strategies. The same instrument has been employed to elaborate on ESP students' reading strategies but without considering the specificity of the ESP context, for instance the use of strategies other than those mentioned in the SORS. It is this specificity that fosters the impetus behind putting into effect the present study at first place, particularly among Algerian ESP students in higher education.

On the other hand, research attempts dealing with metacognitive awareness of reading strategies have also shed light, though marginally, on the aspect of gender differences. As highlighted by Abu-Snouber (2017) "gender differences have been rarely visited by researchers worldwide and the Arab world in general" (p. 01). This is, perhaps, due to the belief of most researchers, investigating language learning strategies use, that females are better than males and more skilled as language learners. Consequently, research on reading strategy usage reveals a gender gap in many contexts where English is taught and learnt as second or foreign language (Poole, 2009). For this, the present research tries also to address this factor in the Algerian context through devoting space for the aspect of gender differences in terms of reading strategy use, mainly among ESP learners.

Eventually, it can be noticed that the issue of investigating reading strategies awareness is still forming wide research gaps in the ESP context in general and in Algeria in particular. Relevant to this, using the SORS as the main research instrument, the present study attempts to fill in one of these gaps through examining reading strategies awareness among Algerian ESP students focusing mainly on the following aspects: (1) the frequency of students' reported use of reading strategies (Global, Problemsolving, and Support reading strategies); (2) differences, if any, between females and males reading strategies use; and (3) students' reported use of any reading strategies other than those included in the SORS. As such, considering these aspects would undoubtedly increase the significance of this study. In that, understanding ESP students' reading strategies awareness and use as well as gender differences in this respect can supply valuable data about students' lacks, wants, and needs regarding the development of their reading strategies which would enable them to get the maximum benefits from reading fieldrelated materials. Then, ESP students' reported use of new reading strategies which are not mentioned in the SORS would hopefully support adapting this instrument to ESP context in order to ensure its relevance to measure ESP students' reading strategies awareness. 


\subsection{Literature review}

In recent decades, language research has witnessed a shift of focus that gives more interest to the learning process at the expense of the teaching process. Accordingly, the learner has become the focal point of several EFL/ESL studies, mainly in terms of awareness, selection, and employment of various learning skills and strategies to understand, learn and acquire knowledge (Oxford \& Cohen, 1992). As put in Oxford's (1990) words, language learning strategies are those "specific actions taken by the learner to make learning easier, faster, more enjoyable, more self-directed, more effective, and more transferable to new situations" (as cited in Roohani et al., 2017, p. 28). Current literature reports that the most significant issues which underpin language learner strategy studies are mainly those focusing on the relationship between reading proficiency and reading strategy use, transfer of L1 reading strategies to $\mathrm{L} 2$ reading, and the role of culture and motivation in reading strategy use, among others.

With reference to the reading skill, available literature accounts for that metacognitive awareness of reading strategies is the salient component of the reading activity that enhances readers' ability to better understand the reading material. In fact, it is often assumed that metacognition involves thinking about learning. It is "an awareness of how one thinks" (Corner, 2003, p. 106). Metacognition is also construed as "the conscious awareness of cognitive processes" (Bernhardt, 1991, p. 52). In the same vein, Flavell (1979), who is credited as the pioneer of the term, views metacognition as the "knowledge that takes as its object or regulates any aspect of any cognitive endeavor" (p. 08). Flavell's definition implies that metacognition revolves around the thought processes the learner utilizes to learn as well as to the selfregulation of cognition. Furthermore, according to Williams and Burden (1997) metacognitive strategies include "ability to manage and regulate consciously the use of appropriate learning strategies for different situations. They involve an awareness of one's mental processes and an ability to reflect on how one learns; in other words, knowing about one's knowing" (p. 148).

As far as reading comprehension is concerned, metacognition pertains to pondering on or thinking about what one is reading. Put another way, it is the reader's reflection on his/her own way of interacting with a given text. Relevant to this, metacognitive reading strategies entail monitoring comprehension and taking measures to increase it through identifying a purpose for reading, planning how the text will be read, self-monitoring for errors in reading comprehension, and self-evaluating how well the objectives are well fulfilled, otherwise corrective measures have to be taken if comprehension is not being achieved (Dhieb-Henia, 2006; Gaith, 2018). Following this tendency, it is quite noticeable that metacognition has a significant role in the process of reading comprehension. For this Janzen (2001) emphasizes that "increased self-awareness of one's process of reading is needed for students to make more efficient use of wider range of strategic behaviors" (as cited in Anderson, 2004, p. 16).

Furthermore, with regard to the consistent process of reading comprehension that is composed of the following phases: before, while, and after reading, researchers have distinguished between three categories of reading strategies, to wit: Global reading strategies, Problem solving strategies and Support reading strategies (Mokhtari \& Sheorey, 2002; Pookcharoen, 2009). The next table gives more insights into these strategies:

Table 1. The three categories of reading strategies (adapted from Mokhtari \& Sheorey, 2002)

\begin{tabular}{|c|c|}
\hline Strategies & Explanation \\
\hline $\begin{array}{l}\text { Global reading } \\
\text { strategies }\end{array}$ & $\begin{array}{l}\text { These are what readers carefully plan to do to monitor/control their reading, e.g. } \\
\text { previewing and predicting the text meaning }\end{array}$ \\
\hline $\begin{array}{c}\text { Problem solving } \\
\text { strategies }\end{array}$ & $\begin{array}{l}\text { These refer to the different actions that readers proceed through while reading, } \\
\text { particularly when they are faced to certain difficulties in the comprehension process of } \\
\text { the printed document, e.g. visualizing the information read, and rereading the passage } \\
\text { to increase understanding }\end{array}$ \\
\hline
\end{tabular}


Support reading strategies
These are what readers rely on to aid augmenting their discernment of the reading material, e.g. annotating, translating, taking notes, or using reference materials like dictionaries and glossaries.

sAs a matter of fact, the findings of most realized research on reading strategies usage among EFL learners reveal the use of global reading strategies by skilled readers more than problem solving and support reading strategies (Amer et al., 2010; Romly et al., 2017).

Concerning the ESP context, several studies have been conducted to assess ESP learners' metacognitive awareness of reading strategies. Some studies were mainly interested in investigating differences between high- and low-level readers (Sheorey \& Baboczky, 2008, as cited in Alhaqbani \& Riazi, 2012; Malcolm, 2009). In these studies, the results have shown that significant differences exist between high and low groups, especially in terms of some particular individual strategies. For example, Malcolm's (2009) survey of reading strategy use among medical students in Bahrain confirmed that translating strategies from English to Arabic were highly deployed among low English proficiency students. Furthermore, another study by Martinez (2008) uncovered that Spanish ESP students tend to show higher reported use frequency of problem solving and global reading strategies.

Other attempts have shed more light on investigating the effects of reading proficiency on the reading process among ESP students. Findings differ from one context to another. For instance, in a Thai preengineering college, high and low proficiency readers shared both differences and similarities in their reading processes (Oranpattanachai, 2010). The utilization of metacognitive reading strategies by proficient ESP readers whose mother tongue is Arabic has also been measured by Alsheikh and Mokhtari (2011). The participants displayed employment of a wider range of reading strategies when reading in English than in Arabic. However, Taiwanese students seem to possess a high level of awareness of overall reading strategies as discovered in a study conducted by Munsakorn (2012).

In the same vein, a study by Omar (2014) investigated the reading strategies employed by a sample of medical sciences students enrolled in an intensive ESP course. The main objective of the study was to determine these students' commonly used reading strategies as well as the strategies they have to develop in order to pursue their academic studies. The findings revealed that the participants used a very limited number of strategies that the author estimated as being poor strategies like word-to-word translation which cannot lead to full comprehension. Therefore, the author suggested some exercises that correspond to each stage of the reading process (before, while, and post-reading) in order to help students advance as strategic and independent readers.

Another research by Terzic (2015) tried to scrutinize types and frequencies of strategies that ESP students made use of while reading academic technical texts. The research was aimed to find out whether students' prior education could affect their different habits of employing reading strategies. The results showed a moderate level of metacognitive reading strategies use among ESP students with Problemsolving strategies reported as the most preferred subscale, followed by Global, then Support strategies as the least used. It was also indicated that there was no statistically significant difference between students' use of the above strategies and their prior education.

Along the same lines, a recent study by Poularvar et al. (2018) has examined ESP students' reading strategies in academic setting. The major purpose of the study was to diagnose Art and Science students' preferred learning styles and the reading strategies they apply most while reading materials in ESP courses. The results of the research confirmed that cognitive strategies were the most dominant reading strategies among both Art and Science students. 
With reference to gender, the majority of studies considering this aspect have shown that there are no significant differences between males and females in terms of reading strategies use (Mokhtari \& Sheorey, 2002; Poole, 2009; Amer et al., 2010). Using the SORS, Poole (2009) compared the reading strategies utilized by male and female college students. Analysis of the obtained data revealed no significant gender differences on any of the three SORS subcategories. Abu-Snouber (2017) also used the SORS to find out gender differences in metacognitive reading strategy use among EFL university students. The findings showed that the participants have a high level of overall strategy use with no significant differences between males and females in all the strategies. As claimed by Abu-Snouber "both males and females equally employed the same strategies with the same order of frequency, ranking problem solving as the most frequently used, followed by support strategies, and reporting global strategies to be the last preferred" (Abu-Snouber, 2017, p. 01).

Almost the same findings have been demonstrated in ESP context. In a recent empirical study Kashef et al. (2015) examined the effect of Strategy-Based Instruction of reading comprehension on Iranian female and male students. The authors proved the effectiveness of the instruction in improving the subjects' reading comprehension but with no significant differences between males and females strategy use. However, in 2008, Martinez conducted a study exploring male and female participants' strategy use among Spanish ESP university students. According to the findings of the study, the females, opting more for support reading strategies, demonstrated a higher level of overall strategy use than males.

Coping with the Algerian context, most researchers dealing with the reading skill in ESP have mainly focused their studies on aspects other than measuring the frequency of students' use of reading strategies and gender differences. These studies tackled issues like problems and difficulties encountered by students when reading in English (Mebarki, 2011). Others emphasized the problematic of raising students' awareness about reading strategies through explicit instruction (Elkouti, 2017). Integration of ICTs also found its way in Algerian ESP studies which were primarily aimed at enhancing students' motivation towards reading (Bouklikha, 2016; Lamri \& Hamzaoui, 2018).

Nevertheless, studies that elaborate on ESP students' use of reading strategies are in fact so limited. For instance, while exploring strands in teaching reading for social sciences, Benabdallah confirmed that psychology students at the University of Tlemcenwere perceived by their teachers as being unconscious of reading strategies. Not only this, but even the concept of reading strategies was ambiguous among some teachers, as put in Benabdallah's (2013) words these teachers "are unfamiliar with the meaning of reading strategies" (p. 05).

In another interesting study, recently conducted, wherein Political Sciences students' reading comprehension difficulties have been investigated by Ladjel and Hamzaoui (2017), the results reported that students' lack of strategic competence created a real handicap for their understanding of specialized material in English. The study also focused on the frequency of reading strategies used by students when dealing with English political texts. As stated by the authors mostly used cognitive strategies were translation, repetition of words and sentences, underlining information ...etc, whereas other cognitive strategies like guessing, elaborating and note taking were seldom employed by the students. Metacognitive strategies, such as monitoring comprehension, planning for reading, and evaluating comprehension, were as well recorded as being rarely used. Eventually, the whole results of the study revealed a remarkable lack of different types of reading strategies use among students which are not only salient when reading texts in a foreign language, but even they affect students' reading comprehension especially in an ESP context.

Eventually, a noteworthy fact is that, though it is internationally recognized as a reliable research instrument for measuring EFL/ESL learners' metacognitive awareness of reading strategies, the SORS has seldom been used in the Algerian context. Perhaps the only available study,which has relied on the 
SORS, has been conducted by Boudaoud (2016) among EFL students who reveal a medium overall use of reading strategies. Furthermore, this same instrument has been employed in several different worldwide contexts and for both EFL and ESP learners, but without taking into consideration the particularity of either context (Martinez, 2008; Munsakorn, 2012; Alsheikh \& Mokhtari, 2011; AbuSnoubar, 2017). As maintained by Samimi et al. (2016), despite its thoroughness Sheorey and Mokhtari's model suffers certain shortcomings since they "look for generalizability rather than particularity of text and context" (p. 112). In fact, adaptations of the SORS have often been limited to modification of some expressions or words to make it comprehensible in some contexts or translation to other languages to measure students' use of reading strategies in languages other than English (Alhaqbani \& Riazi, 2012). Consequently, this study is also aimed to spotlight this gap in the ESP research in general and in the Algerian context in particular.

\subsection{Research questions}

As it has already been mentioned, the importance of reading strategies awareness for foreign language learners has been investigated by many researchers. However, very few are those studies dealing reading strategies awareness and its significance among ESP learners in general and in the Algerian context in particular. Relevant to this, the present research is primarily targeted towards scrutinizing Algerian ESP students' reading strategies awareness when reading academic material in English through putting forward the following research questions:

1. To what extent do the Algerian ESP students tend to use reading strategies when reading academic or school-related material in English?

2. Are there differences between male and female students reported use of reading strategies in Algerian ESP context?

3. Do Algerian ESP students report use of any reading strategies other than those mentioned in the SORS?

\section{Method}

\subsection{Research Design}

This research adopted a mixed-methods case study design wherein both quantitative and qualitative data collection and analysis procedures were used to explore the case of ESP students' strategies while reading specialized material in English at the ENSH. Mixed-methods case study designs can be construed as a research procedure intended for mixing quantitative and qualitative data at any stage of the research in order to provide an in-depth insight and evidence for a case (Creswell \& Plano-Clark, 2018, as cited in Cook \& Kamalodeen, 2019, p. 19). Relevant to this, quantitative data gathered from the Survey of Reading Strategies were used to answer the first research question which concerns the frequency of ESP students' reported use of reading strategies as well as the second research question which seeks information about gender differences in terms of reading strategy use. For the third research question, ESP students' reported use of reading strategies other than those mentioned in the SORS, qualitative data were collected from an open-ended question added at the end of the survey where students could feel freer to express their opinions. As such, integrating qualitative data was supposed to provide greater validity and credibility to the quantitative results. 


\subsection{Participants}

This study was carried out at the National Higher School for Hydraulics (ENSH) of Blida, Algeria, wherein the English language in the field of hydraulics is taught as a compulsory module. The population of this study is represented by 115 students enrolled in the first-year engineering classes during the second semester of the academic year 2016-2017. However, 5 participants were eliminated because some of them were absent during the administration of the research instrument and others gave incomplete responses to the different items of the questionnaire. From the remaining 110, 100 respondents (50 males and 50 females) were randomly taken into consideration in data collection and analysis.

It is worth noting that, in addition to their native language (Arabic or Tamazight), these students study French as a first foreign language and English as a second foreign language, a feature that can be added to the particularity of the Algerian ESP context. Additionally, most, if not all, of theparticipants, whose age ranges between 19 and 23 years old, have been studying English for at least 9 years $(7$ years during their pre-university education and 2 years while attending preparatory university studies in Science and Technology where English is also considered as a compulsory module). Furthermore, after passing the Baccalaureate exam and accomplishing 2 years of prep university studies, these students have to pass a national entrance examination to Higher Schools in order to be able to enroll in first year engineering classes at the ENSH. Moreover, being the teacher of these students, the researcher whose name appears first in this study can evaluate their English language level as being intermediate generally.

On the other hand, the selection of first year engineering classes was done on purpose as the researchers believe that considering the issue of reading strategies in the first year would certainly support students with a solid basis for following the English course in their $2^{\text {nd }}$ and $3^{\text {rd }}$ year classes.

\subsection{Instrument}

The present research made use of the Survey of Reading Strategies (SORS) as a research instrument for data collection. Based on the Metacognitive Awareness of Reading Strategies Inventory (MARSI), the SORS is designed by Mokhtari and Sheorey (2002), and it is aimed at measuring ESL students' reported strategy use while reading academic documents in English. As confirmed by Mokhtari et al. (2018) "the primary purpose of MARSI and SORS is to assess students' metacognitive awareness or perceived use of reading strategies when reading texts for academic purposes" (p. 222). These selfmeasures, according to the same authors, should be used to tap students' perceptions of reading strategy use when reading in general rather than for a given text or task. Also noteworthy is that students' level of English proficiency is foundational in determining which measure to opt for, in that "for students with advanced levels of English proficiency, either measure is fine to use. However, there is a practical value in using the SORS when assessing students with lower levels of English proficiency" (Mokhtari et al., 2018, p. 239). Therefore, with reference to our teaching experience as well as students' English exam papers and different classroom tasks, students' level of English proficiency at ENSH can be depicted as being intermediate. Thus, the SORS is found more suitable to opt for as a measure instead of the MARSI.

The SORS consists of three categories which group 30 items that can be categorized into three subscales or factors. The first category or factor is called Global Reading Strategies and it contains 13 items designed to assess a global analysis of texts, for example this item "I have a purpose in mind when I read". The second subscale is named Problem-solving strategies. It contains 8 items which represent asset of reading strategies oriented towards solving problems when text becomes difficult to read. One example of these strategies is "I adjust my reading speed according to what I read". The third category of strategies is labeled Support Reading Strategies and it includes 9 items. It mainly involves the use of 
extra reference materials like dictionaries, or taking notes, and other practical strategies that can be depicted as functional or support strategies. These can be exemplified by "I take notes while reading" and "I underline or circle information in the text to help me remember it". Moreover, the SORS consists of 5-point Likert scale (from $1=$ never do this to $5=$ always do this). The mean scores from the SORS are divided into three groups: 3.5 or higher $=$ high; $2.5-3.4=$ medium; 2.4 or lower $=$ low. The SORS was administrated in its original form, and by the end the students were required to add any other strategy they use in reading but it is not mentioned in the SORS. Furthermore, using Cronbach coefficient alpha, the reliability of the survey was estimated at 0.800 .

The utilization of the SORS in this study is mainly aimed at finding out and analyzing the participants' reported use of reading strategies displayed throughout the 30 items of the SORS; differences, if any, between males and females strategy use; as well as students' use of strategies other than those included in this research instrument, so that to adapt it to the Algerian ESP context.

\subsection{Data collection and analysis}

Data were collected during the second semester of the 2016-2017 academic year at the ENSH by means of the SORS. During the administration of the SORS by the researcher to first year ESP classes, participants were informed about the content of the study as well as its purpose and importance. To ensure confidentiality, students were advised not to write their names on the questionnaire. Furthermore, students were asked to frankly respond to each item; i.e. respond to the strategy that reflect their way of reading, bearing in mind that there are no right or wrong answers. Explanations of items that seem difficult for the students were also provided by the researcher to facilitate the process of collecting data. After approximately 20 minutes, all the participants were able to finish their responses and hand back the questionnaire to the researchers.

As for analysis, the data collected were treated and analysed through descriptive statistics using SPSS version23. This is particularly for the first and second research questions where calculations of frequency, mean scores and standard deviations are highly required. However, the qualitative data that correspond to the third research question were treated through interpretation and descriptive analysis of the participants' responses.

\section{Results}

This section reports the findings obtained from ESP students' responses to the SORS at the ENSH, and which correspond to the research questions raised at the beginning of this paper. In other words, this section exposes and explains relevant answers that pertain to: the frequency of Algerian ESP students reported use of reading strategies, gender differences in reading strategies use among Algerian ESP, as well as students reported use of other reading strategies which are not mentioned in the SORS.

\subsection{Frequency of Algerian ESP students reported use of reading strategies}

The first research question cited above is answered through detecting the frequency of reading strategies use by the participants in terms of the three categories (Global strategies, Problem solving strategies, and Support reading strategies) separately, and then the overall use of all categories conjointly. Relevant to this, the overall average of reading strategies use by the whole population as well as the mean scores of each category are calculated and displayed in tables 2, 3, and 4 hereinafter. 
Table 2. Students' overall use of reading strategies

\begin{tabular}{cccccc}
\hline & Frequency & Percent & $\begin{array}{c}\text { Valid } \\
\text { percent }\end{array}$ & $\begin{array}{c}\text { Cumulative } \\
\text { Percent }\end{array}$ \\
\hline Valid & High & 30 & 30.0 & 30.0 & 30.0 \\
& Medium & 60 & 60.0 & 60.0 & 90.0 \\
& Low & 10 & 10.0 & 10.0 & 100.0 \\
& Total & 100 & 100.0 & 100.0 & \\
\hline
\end{tabular}

Table two above reveals the overall average of reading strategies used by ESP students at the ENSH when reading academic material in English. As it can clearly be noticed the majority of the students present a medium level of reading strategies use with the frequency of $60 \%$. On the other hand, only $30 \%$ of the participants can be described as high users of reading strategies, whereas the remaining $10 \%$ show a low level of reading strategies use.

Table 3. Frequency of students reported use of reading strategies by category

\begin{tabular}{cccccc}
\hline & Frequency & Percent & Valid Percent & $\begin{array}{c}\text { Cumulative } \\
\text { Percent }\end{array}$ \\
\hline Valid & GLOB & 9 & 9.0 & 9.0 & 9.0 \\
& PROB & 80 & 80.0 & 80.0 & 89.0 \\
& SUP & 11 & 11.0 & 11.0 & 100.0 \\
& Total & 100 & 100 & 100.0 & \\
\hline
\end{tabular}

Data related to the frequency of students' reported use of reading strategies by category is exposed in table 3. Accordingly, problem solving strategies are evidently the most employed reading strategies among ESP students (80\%) at ENSH. In second place, the use of support reading strategies scored $11 \%$. Finally, global reading strategies represent $9 \%$ only, to be as such the least used category of strategies by the participants.

Furthermore, the mean score of the three categories of reading strategies separately is also calculated. As revealed in table 4 below, the highest mean is obviously scored by Problem-solving strategies and it is estimated at 3.70. After that, Global reading strategies reach the mean of 3.23. Eventually, the least used category which is Support reading strategies scores the mean of 2.81. This entails the result that Algerian ESP students tend to use Problem-solving strategies while reading academic or school-related material in English more than Global and Support reading strategies. The representation of all these findings are shown in table 4 hereinafter.

Table 4. Mean scores of students' reported use of reading strategies by category

\begin{tabular}{ccccc}
\hline & Global strategies & $\begin{array}{c}\text { Problem solving } \\
\text { strategies }\end{array}$ & $\begin{array}{c}\text { Support } \\
\text { strategies }\end{array}$ \\
\hline $\mathrm{N}$ & Valid & 100 & 100 & 100 \\
& Missing & 0 & 0 & 0 \\
\hline Mean & & 3.2316 & 3.7033 & 2.8120 \\
\hline
\end{tabular}

\subsection{Gender differences in reading strategies use among Algerian ESP students}

This research question is answered through calculating the mean scores of different categories of reading strategies use by males and females. Details are presented in the following table. 
Table 5. Mean scores of overall strategy use by gender

\begin{tabular}{lccc}
\hline Male and female & Mean & $\mathrm{N}$ & $\begin{array}{c}\text { Std. } \\
\text { Deviation }\end{array}$ \\
\hline Female & 3.1676 & 50 & .72864 \\
Male & 3.2816 & 50 & .33020 \\
Total & 3.2246 & 100 & .56571 \\
\hline
\end{tabular}

As it can be seen, table five presents the scores of overall use of reading strategies by whole population (mean $=3.22$ ) as well as by gender (females: mean=3.16, males: mean=3.28). Following the classification of mean scores (see Instrument), the level of reading strategies use by Algerian ESP students is medium both among the whole population as well as among females (mean=3.22) and males (mean=3.28) separately.

Furthermore, the mean scores of reading strategies by category and gender are also calculated. According to table six below, global strategies are reported to be used by female students (mean $=3.24$ ) more than males (mean=3.21). However, problem solving strategies have a high score among males $(m e a n=3.78)$ rather than females (3.61). The same can be noticed for support strategies, in that males $(m e a n=2.87)$ tend to use this type of reading strategies more than females do (mean=2.75).A clear representation of these findings is displayed in the following table.

Table 6. Mean scores of reading strategies use by category and gender

\begin{tabular}{ccccc}
\hline \multicolumn{2}{c}{ Male and female } & Global strategies & $\begin{array}{c}\text { Problem solving } \\
\text { strategies }\end{array}$ & Support strategies \\
\hline Female & Mean & 3.2490 & 3.6186 & 2.7534 \\
& $\mathrm{~N}$ & 50 & 50 & 50 \\
\multirow{4}{*}{ Male } & Std. Deviation & .73687 & .98612 & .72041 \\
& Mean & 3.2142 & 3.7880 & 2.8706 \\
& $\mathrm{~N}$ & 50 & 50 & 50 \\
Total & Std. Deviation & .45147 & .41079 & .66327 \\
& Mean & 3.2316 & 3.7033 & 2.8120 \\
& N & 100 & 100 & 100 \\
& Std. Deviation & .60822 & .75636 & .69144 \\
\hline
\end{tabular}

\subsection{Algerian ESP students report use of reading strategies other than those mentioned in the SORS}

The third research question of the present study revolved around ESP students' report use of reading strategies other than those mentioned in the SORS of Mokhtari and Sheorey (2002). To answer this research inquiry an open-ended question was added at the end of the survey asking the participants to demonstrate any other strategy they use while reading academic texts in English but it is not included in the survey given to them. Not only this, but the students were also allowed to make some comments and suggestions concerning the difficulty of understanding the items and their organization within the questionnaire. All these remarks have been taken into consideration by the researchers in the process of adapting the SORS to ESP context in Algerian higher education.

According to the participants' responses, Algerian ESP students tend to use some reading strategies which are not mentioned in the SORS. For example, one of the participants stated "when I read in English and I don't understand, I translate words into French because we use it in our specialty more than our native language. I also ask the teacher of English or my classmates to help me". Another participant claimed "when I read in English, I translate difficult words into French because we use it 
very much in hydraulics and in the end I make a list of new words to remember them better. I also prefer to discuss the topics we read in classroom to understand more". Another statement by another participant explained "when I don't understand a text in English, I translate words into Arabic or French. When I can't translate, I ask my friends or my teacher of English to explain for me and sometimes I ask my teachers of hydraulics because they have more knowledge."

With reference to the above statements, it can be noticed that there are some strategies that ESP students used to employ while reading in English and these strategies were not accounted for by Mokhtari and Sheorey, and even by researchers who used the SORS in ESP context, indeed. Among these strategies are the following:

- Translation into not only the native language which is Arabic in this case study, but also into the first foreign language which is French (this is mainly because French is the medium of instruction for almost all technical courses in Algerian higher education).

- Seeking help of classmates, English teacher, subject specialists, particularly when meaning cannot be achieved even through translation.

- Checking understanding through discussion with classmates, English teacher, subject specialists.

- Make a list of new words and terminology to learn and build vocabulary.

Furthermore, with regard to the remarks and suggestions addressing the categorization of reading strategies, it is found that all the participants perceive the concepts of global, problem-solving and support reading strategies as being strange for them. This requires the researchers to opt for another categorization of these strategies in a very simple way that can respond to ESP students' linguistic level since they are not language specialists.

Finally, some other items have been added by the researchers. These items are believed to be particular to the ESP context like collaboration with subject specialists, distinction of fact from opinion, identifying typical structure of scientific text (cause/effect, problem/ solution, processing ...etc.). All in all, an adapted version of the SORS (see Appendix) is suggested by the researchers to fit within the context of ESP teaching/learning at least in Algerian higher education.

\section{Discussion}

In relation to data analysis mentioned above, it can be presumed that Algerian ESP students, mainly at the ENSH, tend to frequently use reading strategies in general though to varying degrees. In fact, many other studies have described language learners as being frequent users of reading strategies since they are always in search of different ways or techniques that may enable them to facilitate the process of reading comprehension as much as possible (Pookcharoen, 2009). Furthermore, another significant finding reports that the use of problem-solving strategies is more frequent among ESP students than global and support reading strategies. This finding is as well confirmed by other recent studies (Martinez, 2008; Poularvar et al., 2018; Terzic, 2015). This may justify Algerian ESP students' perception of reading in English as a problem-solving process.

Moreover, global reading strategies score second place; this, indeed, is consistent with a study carried out in the Spanish context (Martinez, 2008) and another study conducted by Terzic (2015) in the Croatian context. In fact, the use of global strategies is conceived as the typical feature of skilled readers who tend to rely on this category of reading strategies more than the other two categories (problem solving and support reading) as exposed in various researches (Amer et al., 2010; Romly, et al., 2017). Accordingly, it can be assumed that students at ENSH are not good readers of English due to their 
ignorance of reading strategies which may undoubtedly affect their academic achievement. In this case, as reviewed by Karbalaei (2010, p. 175), Pressley \& Afflerbach (1995) argued that teachers can assist their students to become "constructively responsive" readers through enhancing their awareness of such strategies. In the same vein, Martinez (2008) confirmed that "teaching students to become constructively responsive readers can be a powerful way to promote skillful academic reading, which will, in turn, enhance academic achievement" (p. 173).

Furthermore, support reading strategies like taking notes while reading, underline or circle information in the text to remember it, and the use of reference materials (e.g., dictionaries), among others, are the least used reading strategies by ESP students at ENSH. Similarly, ESP students in Croatia also demonstrated the same tendency in the study of Terzic (2015) where support strategies were revealed as the least employed subscale preceded by problem solving strategies as the most useful, then global reading strategies. Yet, it is worth noting that students' ignorance of the importance of such strategies would hinder their ability to achieve full understanding of the reading material. As maintained by Mokhtari and Sheorey (2002), support reading strategies are "basic support mechanisms intended to aid the reader in comprehending the text" (p.06).

Meanwhile, the overall score of reading strategies presented Algerian ESP students as moderate users of reading strategies with an overwhelming medium level. This finding is convergent with Benabdellah's (2013) study which, as already mentioned in the literature, confirmed Algerian ESP students' unconsciousness about reading strategies. In a similar way, the results of Ladjel and Hamzaoui's (2017) research validated the fact that Algerian ESP students lack strategic reading competence. In fact, these overlapping findings can be construed in relation to students' ignorance of the existence of these strategies as well as their use. As a consequence, the issue of raising students' awareness about all categories of reading strategies and how and when they can be used must be taken seriously by every responsible in the field as soon as possible.

Concerning the variable of gender, it was found that there is no statistically significant difference between males and females in overall use of reading strategies. This finding matches recent literature on gender and reading strategies use which has not shown remarkable variations in terms of strategy use between males and females (Mokhtari \& Sheorey, 2002; Poole, 2009; Amer et al., 2010). Even with reference to the three categories, males and females revealed approximately the same level. What is perhaps remarkable is that females attained high scores in global strategies while high scores in both problem solving and support strategies were attained by males. Thus, it seems that females try to monitor their reading process more than males. However, generally it can be deduced that gender has no impact on reading strategy use.

On the other hand, the data analysis also highlighted the non-convergence of Mokhtari and Sheorey's SORS with ESP context. The latter's peculiarity imposes new items that should be added to the questionnaire to effectively respond to the reading practice of ESP students in their specific context which involves besides the reader and the text, the language teacher and the subject specialist. In fact, this gap in Mokhtari and Sheorey's survey has also been drawn attention to by other studies (Samimi et al., 2016). Therefore, a new adapted version of the survey of reading strategies is designed to cope with ESP students' needs at least within the local level. Even the categorization of the survey's items has been taken into consideration to cope with the linguistic level of ESP students who revealed certain confusion in understanding expressions like global, problem-solving, and support reading strategies. Then, as cited by Zhang (2008, p. 99), O'Malley and Chamot (1990) advised that "the optimum way of grouping strategies" is to "minimize potential learner confusion". Accordingly, the items of the survey have been reorganized into: Pre-reading, While-reading, and Post-reading strategies reflecting in such a simple way the three stages of the reading process that any language learner can comprehend as referring to the strategies used before reading, during reading, and after reading a given text. 
Overall, this study has provided thoughtful information about ESP students reading strategies awareness, especially in terms of frequency of reading strategies use and gender differences among ESP students as well as the existence of reading strategies which are particular to ESP context. With reference to the results, this study, like many other similar studies, has confirmed ESP students' moderate use of reading strategies and the non-existence of statistically significant differences between females and males' deployment of these strategies. These findings are very important in sustaining ESP researchers in understanding the way ESP students tackle field-related materials and the extent to which they are aware of the existence of valuable strategies that can help them proceed easily through the reading process and get the maximum benefit out of their academic resources. On the other hand, findings concerning the third research question justified the peculiarity of reading strategy use in the ESP context which has to be taken into consideration while utilizing reading strategies measurements like the SORS. Therefore, it can be concluded that taking this study's findings seriously would help to increase ESP students' moderate level of reading strategies use into a higher level so that they can develop not only as strategic readers but even as successful language learners.

\section{Conclusions}

This study unveiled an examination of Algerian ESP students' awareness of reading strategies, especially when dealing with specialized material in English. For this, Mokhtari and Sheorey's SORS was used as the major research tool to collect data concerning reading strategies use among first year ESP students at the ENSH. The main objective of the study revolved around finding out whether these students could be depicted as frequent users of reading strategies or not. Relevant to this, the focal point of the research proceeded through diagnosing overall average of reading strategies as well as the frequency of students' reported use of each category of strategies, namely: global, problem solving, and support reading strategies. The obtained results revealed Algerian ESP students as being moderate strategic readers with overemphasis on problem solving as mostly used reading strategies. The study also sought to identify any gender differences in reading strategy use. The findings demonstrated that variations between males and females strategy use were not statistically significant. Another focus of this study involved students' report use of reading strategies other than those included in the SORS. Students' responses uncovered the existence of particular reading strategies to ESP context which have to be taken into consideration while using the SORS with ESP students.

Based on these findings, the study brought significant implications for students, teachers and course developers in ESP context. Relevant to this, ESP students have to be aware of the importance of the reading activity which cannot be interesting and fruitful unless it is approached in a strategic way. Concomitantly, ESP teachers and course developers must rethink their vital role in enhancing ESP students reading strategic competence mainly through highlighting some aspects which are particular to ESP reading context like specialized terminology and the subject specialist collaboration that can provide assistance to ESP readers. These aspects have to be emphasized by course developers during ESP course design as well as by teachers during instruction of reading strategies that must be explicit and overt. All in all, every active agent in the ESP field has to be aware of every tiny particular element that can affect the development of ESP students' strategic competence in general and in the reading skill in particular.

Eventually, research on reading strategies,especially among ESP students, still needs more efforts to fill in its pertinent gaps with special reference to the local context. Thus, for further research this study suggests exploring the importance and possible ways to raise Algerian ESP students' awareness of reading strategies which has to be pondered on seriously and urgently. Also worth consideration is that 
students have to be explicitly instructed in how to manage with the activity of reading as a multifaceted process to be able to move on beyond the literal meaning towards the critical analysis of the specialized material.

\section{Ethics Committee Approval}

The author(s) confirm(s) that the study does not need ethics committee approval according to the research integrity rules in their country (Date of Confirmation: December 11, 2020).

\section{References}

Abu-Snoubar, T. (2017). The metacognitive reading strategies employed by Jordanian English as foreign language students at Al-Baqa applied university. Journal of Literature, Languages and Linguistics, 35, 16-27.

Amer, A. et al. (2010). Students' teachers perceived use of online reading strategies. International Journal of Education and Development Using Information and Communication Technology (IJEDICT), 6(4), 102-113.

Alhaqbani, A., \& Riazi, M. (2012). Metacognitive awareness of reading strategy use in Arabic as a second language. Reading in a Foreign Language, 24(2), 231-255.

Alsheikh, N., \& Moukhtari, K. (2011). An examination of metacognitive reading strategies used by native speakers of Arabic when reading in English and Arabic. English Language Teaching, 4(2), 151-160.

Anderson, N. J. (2004). Metacognitive reading strategy awareness of ESL and EFL learners. The CATESOL Journal, 16(1), 11-27.

Benabdallah, A. (2013). Strands in teaching reading for social sciences: Change and innovation. English for Specific Purposes World, 14(38), 1-9.

Bernhardt, E. B. (1991). Reading development in second Language: Theoretical, empirical, and classroom perspectives. Ablex Publishing.

Boudaoud, R. (2016). Implementing a reading strategy-based instruction for promoting students' achievement and self-regulation: In curricular skill integration perspectives: The case of first year students, University of Constantine (Unpublished doctoral dissertation). University of Mentouri Bros. Constantine.

Bouklikha, W. (2016). Practice of the reading skill in an ESP context using web-retrieved materials: The case of engineering students at the University of Tlemcen (Unpublished doctoral dissertation). University of Tlemcen.

Cook, D. L., \& Kamalodeen, J. V. (2019). Mixed methods case study research. Mixed Methods International Research Association. Webinar. Retrieved on Sep 13, 2020 from https://www.ualberta.ca/international-institute-for-qualitative-methodology

Corner, P. (2003). Strategies for teaching science content reading. The Science Education Review, 2(4), 104-119.

Dhieb-Hania, N. (2006). Applying metacognitive strategies to skimming research articles in an ESP context. English Teaching Forum, 44(1). 
Elkouti, M. (2017). The Impact of text structure on ESP learners' reading comprehension: Case study: accounting and finance at the University of Ghardaia (Unpublished doctoral dissertation). University of Ourgla.

Flavell, J. H. (1979). Metacognition and cognitive monitoring: A new area of cognitive-developmental inquiry. American Psychologist, 34(10), 906-911.

Gaith, G. (2018). English as a second/foreign language reading comprehension: A framework for curriculum and instruction. TESL Reporter, 50(2), 1-17.

Johns, A.,\& Dudley-Evans, T. (1991). English for specific purposes: International in scope, specific in purpose. TESOL Quarterly, 25(2), 297-314.

Karbalaei, A. (2010). A comparison of the metacognitive reading strategies used by EFL and ESL readers. The Reading Matrix, 10(2), 165-180.

Kachef, S., Damavand, A., \& Viyani, A. (2012). Strategy-based ESP instruction (SBI) of reading comprehension: Male vs. female students. International Journal of Education,4(2), 171-180.

Kymes, A. (2007). Investigation and analysis of online reading strategies.Oklahoma State University.

Ladjel, K., \& Hamzaoui-Elachachi, H. (2017). Improving political sciences students' reading comprehension of English texts. The Journal of Teaching English for Specific and Academic Purposes, 5(4), 755-770.

Lamri, C., \& Hamzaoui-Elachachi, H. (2018). Developing ELP students' reading skills through a blended learning approach. Eurasian Journal of Applied Linguistics, 4(2), 389-407.

Malcolm, D. (2009). Reading strategy awareness of Arabic speaking medical students studying in English. System, 37, 640-651.

Martinez, A. C. (2008). Analysis of ESP university students' reading strategy awareness. IBERICA, 15, 165-176.

Mebarki, Z. (2011). Factors underlying the reading performance of Algerian microbiology students. International Conference on Education and Educational Psychology.

Mokhtari, K., Dimitrov, D., \& Reichard, C. (2018). Revising the "metacognitive awareness of reading strategies inventory" (MARSI) and testing for factorial invariance. Studies in Second Language Learning and Teaching, 8, 219-246.

Mokhtari, K., \& Sheorey, R. (2002). Measuring ESL students' awareness of reading strategies. Journal of Developmental Education, 25(3), 2-10.

Munsakorn, N. (2012). Awareness of reading strategies among EFL learners at Bankok University. International Journal of Social and Human Sciences, 6, 497-500.

Omar, A. (2014). An investigation into the reading strategies of ESP students in the college of medical sciences at Umm Al-Qura University. Journal of Languages and Literatures, 13, 5-46.

Oranpattanachai, P. (2010). Perceived reading strategies used by Thai pre-engineering students. $A B A C$ Journal, 30(2), 26-42.

Oxford, R. \& Cohen, A. (1992). Language learning strategies: Crucial issues of concept and classification. Applied Language Learning, 3(1\&2), 1-35.

Pani, S. (2004). Reading strategy instruction through mental modeling. ELT Journal,58(4), 355-362. Oxford University Press. 
Pookcharoen, S. (2009). Metacognitive online reading strategies among Thai EFL University students (Unpublished doctoral dissertation), Indiana University.

Poole, A. (2009). The reading strategies used by male and female Colombian university students. Profile: Issues in Teachers' Professional Development, (11), 29-40.

Poularvar, K., Zohrabi, M., \& Ajideh, R. (2018). Investigating the relationship between learning styles and ESP reading strategies in academic setting. International Journal of Applied Linguistics and English Literature, 7(3), 156-164.

Rezaei, A., Rahimi, M., \& Talepazan, S. (2012). Exploring EFL learners' reading comprehension problems in reading ESP texts. Sino-US English Teaching, 9(3), 982-987.

Romly, R., Badusan, J., \& Maarof, N. (2017). Metacognitive online reading strategies in reading academic texts among ESL University students. Conference paper. Seminar on Trans-Disciplinary Education (STED 2017). https://sted2017.wordpress.com/proceeding/

Roohani, A., Sabzeali, R., \& Mirzaei, A. (2017). Exploring metacognitive strategies in reading academic texts among more and less proficient EFL university students. English Language Teaching, 4(4), 123-142.

Samimi, F., Sahragard, R., \& Ramzjoo, S. (2016). On the development of a model of discipline-specific reading strategies in the context of Iranian EFL learners. International Journal of Foreign Language Teaching and Research, 4(15), 99-115.

Terzic, B. B. (2015). Metacognitive awareness of reading strategies among ESP students regarding their prior education. The Journal of Teaching English for Academic and Specific Purposes, 3(2), 257268.

Willaims, M., \& Burden.R. (1997). Psychology for language teachers. Cambridge University Press.

Zhang, L. J. (2008). Constructivist pedagogy in strategic reading instruction: Exploring pathways to learner development in the English as a second language (ESL) classroom. Instructional Science, $36,89-116$.

\section{Appendix}

\section{ESP Students' Reading Strategies Awareness Questionnaire}

(Adapted from Mokhtari and Sheory's SORS, 2002)

The purpose of this questionnaire is to collect information concerning the strategies you use while reading academic materials in English (e.g. reading examination texts). Each item in the questionnaire is followed by 4 numbers 1,2 , 3 and 4 , and each number means the following:

" 1 " = 'I never do this'; " 2 " = 'I rarely do this'; " 3 " = 'I frequently do this'; "4" = 'I always do this'

After reading each statement, circle the number (1, 2, 3 or 4) which applies to you. You should know that there are no right or wrong responses to any of the items of the questionnaire.

\begin{tabular}{|c|c|c|c|c|c|}
\hline $\mathbf{N}^{\circ}$ & Pre-reading Strategies & \multicolumn{4}{|c|}{ Scale } \\
\hline 01 & $\begin{array}{l}\text { I establish a purpose for reading through raising some questions I like to have answered in } \\
\text { the text }\end{array}$ & 1 & 2 & 3 & 4 \\
\hline 02 & I make a list of all ideas I may have about the topic of the text & 1 & 2 & 3 & 4 \\
\hline 03 & I make a list of predictions to anticipate possible content of text & 1 & 2 & 3 & 4 \\
\hline 04 & $\begin{array}{l}\text { I look at the text surface features and organizational clues (e.g. titles, subtitles, diagrams, } \\
\text { etc.) }\end{array}$ & 1 & 2 & 3 & 4 \\
\hline 05 & $\begin{array}{l}\text { I make some comments on organizational aspects of text (e.g. title, author, source, visual } \\
\text { aids, etc.) }\end{array}$ & 1 & 2 & 3 & 4 \\
\hline
\end{tabular}




\begin{tabular}{|c|c|c|c|c|c|c|}
\hline \multicolumn{7}{|c|}{ While-reading Strategies } \\
\hline 06 & \multicolumn{2}{|l|}{ I read headings and subheadings, etc. to understand the organization of text } & 1 & 2 & 3 & \\
\hline 07 & \multicolumn{2}{|l|}{ I keep raising questions in mind about the text } & 1 & 2 & 3 & 4 \\
\hline 08 & \multicolumn{2}{|l|}{ I skim the text to get the general idea } & 1 & 2 & 3 & 4 \\
\hline 09 & \multicolumn{2}{|l|}{ I read aloud to concentrate well and understand what I read. } & 1 & 2 & 3 & 4 \\
\hline 10 & \multicolumn{2}{|l|}{ I try to guess the meaning of difficult words through contextual clues. } & 1 & 2 & 3 & 4 \\
\hline 11 & \multicolumn{2}{|l|}{ When guessing meaning from context is also difficult, I use translation into Arabic or French } & 1 & 2 & 3 & 4 \\
\hline 12 & \multicolumn{2}{|l|}{$\begin{array}{l}\text { When translation doesn't help, I ask another person (e.g. classmate, English teacher, subject } \\
\text { specialist) }\end{array}$} & 1 & 2 & 3 & 4 \\
\hline 13 & \multicolumn{2}{|l|}{ I read slowly and carefully when looking for specific information } & 1 & 2 & 3 & 4 \\
\hline 14 & \multicolumn{2}{|l|}{ I connect what I read to what I already know while reading } & 1 & 2 & 3 & 4 \\
\hline 15 & \multicolumn{2}{|l|}{ I annotate and mark the text while reading } & 1 & 2 & 3 & 4 \\
\hline 16 & \multicolumn{2}{|l|}{ I summarize the general idea of each paragraph in written form } & 1 & 2 & 3 & 4 \\
\hline 17 & \multicolumn{2}{|l|}{ I look for logical relationships between paragraphs. } & 1 & 2 & 3 & 4 \\
\hline 18 & \multicolumn{2}{|l|}{ I look for logical relationships between paragraphs and visual aids (e.g. diagrams...) } & 1 & 2 & 3 & 4 \\
\hline 19 & \multicolumn{2}{|l|}{ I identify main idea and supporting details of each paragraph. } & 1 & 2 & 3 & 4 \\
\hline 20 & \multicolumn{2}{|l|}{$\begin{array}{l}\text { I identify the organizational aspects of text in terms of its typical structure (e.g. cause/effect, } \\
\text { compare/contrast, etc.) }\end{array}$} & 1 & 2 & 3 & 4 \\
\hline 21 & \multicolumn{2}{|l|}{ I verify my understanding of text with classmates or teacher. } & 1 & 2 & 3 & 4 \\
\hline 22 & \multicolumn{2}{|l|}{$\begin{array}{l}\text { I control my understanding of text by identifying topic sentences of paragraphs or inventing } \\
\text { topic sentences if none exist }\end{array}$} & 1 & 2 & 3 & 4 \\
\hline 23 & \multicolumn{2}{|l|}{ I take notes while reading to understand what I read. } & 1 & 2 & 3 & 4 \\
\hline 24 & \multicolumn{2}{|l|}{ I re-read text to check my understanding } & 1 & 2 & 3 & 4 \\
\hline 25 & \multicolumn{2}{|l|}{ I examine ideas to make difference between fact and opinion } & 1 & 2 & 3 & 4 \\
\hline \multicolumn{7}{|c|}{ Post-reading Strategies } \\
\hline 26 & I check if my predictions about the text are right or wrong & 1 & 2 & 3 & & \\
\hline 27 & $\begin{array}{l}\text { I examine how well text is understood through discussion with classmate, English teacher, } \\
\text { subject specialist }\end{array}$ & 1 & 2 & 3 & & 4 \\
\hline 28 & I make critical comments on text & 1 & 2 & 3 & & 4 \\
\hline 29 & I re-read to summarize the text & 1 & 2 & 3 & & 4 \\
\hline 30 & I check if the questions raised at the beginning are answered in the text & 1 & 2 & 3 & & 4 \\
\hline 31 & I check to what extent my purpose of reading is fulfilled & 1 & 2 & 3 & & 4 \\
\hline 32 & I make a list of new words and terminology to learn and build vocabulary & 1 & 2 & 3 & & 4 \\
\hline
\end{tabular}

\section{ESP Students' Reading Strategies Awareness Questionnaire Scoring Rubric}

1. Write your response to each statement (e.g. 1, 2, 3, 4 or 5) in each of the blanks below.

2. Add up the scores under each column. Place the result on the line under each column.

3. Divide the score by the number of statements in each column to get the average for each subscale.

4. Calculate the average for the survey by adding up the subscale scores and dividing by 32

5. Compare your results with those shown below. 


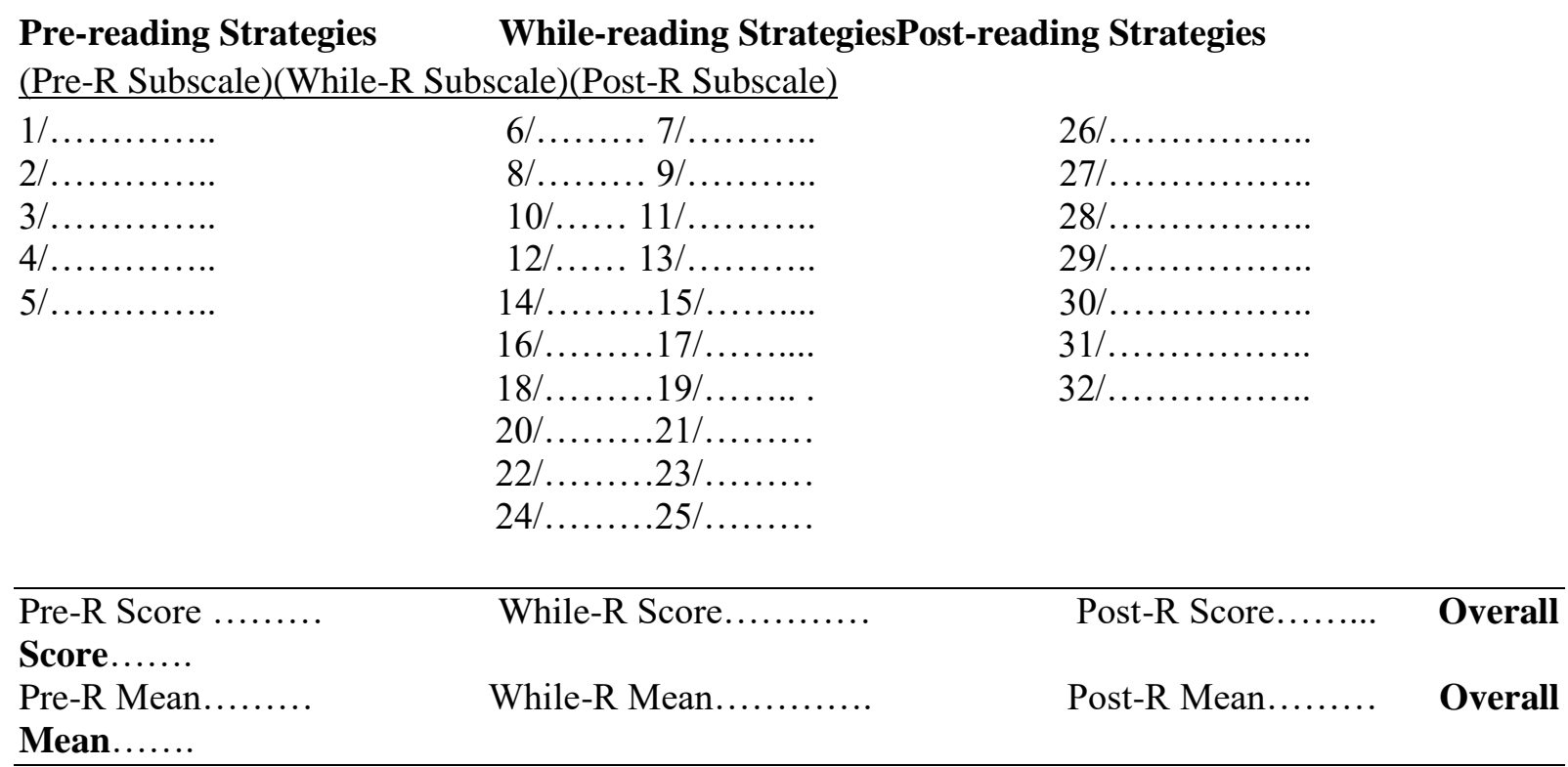

\title{
Ulusal Hidrolik Yüksek Okulu'ndaki Cezayirli ESP öğrencileri arasında okuma stratejileri farkındalığının incelenmesi
}

\begin{abstract}
$\ddot{O} \mathbf{z}$
Öğrencilerin okuma sürecine ilişkin bilgilerinin yanı sıra okuma stratejileri konusundaki üstbilişsel farkındalıklarının teşvik edilmesi, ESP öğretiminin önemli bir konusu ve şüphesiz yüksek öğrenim zorunlu bir konu haline geldi. Bununla ilgili olarak, bu makale Cezayirli ESP öğrencilerinin farkındalıklarını ve özellikle akademik konuları İngilizce okurken okuma stratejilerini kullanmalarını incelemeye çalışmaktadır. Bu çalışma, Mokhtari ve Sheorey'in (2002) Okuma Stratejileri Araştırması'nın (SORS) yönetimi aracılığıyla Ulusal Hidrolik Yüksek Okulunda (ENSH) birinci sınıf mühendislik derslerine kaydolan 100 öğrenciye esas olarak şu noktaları öğrenmek için yapılmıştır: 1) öğrencilerin farklı okuma stratejileri kullandığını bildirme sıklığı (Küresel, Problem Çözme ve Destek Okuma Stratejileri); 2) fark (lar) Eğer varsa, kız ve erkek öğrencilerin okuma stratejileri arasında kullanımı; ve öğrenciler, SORS'a dahil olmayan diğer stratejileri kullanıldığını bildirilmiştir; 3) öğrenciler, SORS'da yer almayan diğer stratejileri kullandıklarını bildirilmiştir. Bulgular, genel olarak okuma stratejilerinin ortak kullanıcıları olan Cezayirli ESP öğrencilerinin, problem çözmeyi diğer okuma stratejileri kategorilerinden daha fazla kullanma eğiliminde olduklarını ortaya koymaktadır; erkekler ve kadınlar arasında önemli farklılıkların olmaması okuma stratejilerinin kullanıldığını bildirmiştir; bu arada öğrenciler, Mokhtari ve Sheorey'in anketinde bahsedilenler dışındaki bazı stratejilerin kullanıldığını bildiriyor. Sonuç olarak, SORS'un uyarlanmış bir versiyonu, belirli amaçlar için Cezayir EFL bağlamına uyacak şekilde tasarlanmıştır.
\end{abstract}

Anahtar sözcükler: okuma stratejileri; Cezayirli ESP öğrencileri; SORS; üstbilişsel farkındalık; cinsiyet; okuma 


\section{AUTHOR BIODATA}

Safia Bensaad is an associate professor of English at the National Higher School for Hydraulics in Algeria. She holds a Magister in English Language and Civilization. She is now pursuing her PhD research in English for Specific Purposes. She has participated in national and international conferences. Her research interests include, besides ESP, critical reading, teacher development, and lifelong learning.

Ghania Ouahmiche is a professor at the department of foreign languages at Oran 2 university in Algeria. She holds a $\mathrm{PhD}$ in Foreign Language Teaching and Language Sciences (French language and Francophone literature) and a $\mathrm{PhD}$ in Sociolinguistics and language planning (English language). Her research interests include but not limited to: foreign language teaching methodology, sociolinguistic variation, language policy and planning. 